\title{
RELIGIOUS AND CULTURAL REFERENCES OF TURKISH MIND AND TURKISH SUFISM: YESEVISM
}

\author{
${ }^{1}$ İsmail Taş, ${ }^{2}$ Havva Sümeyra Altınsoy \\ 1'hacili1965@hotmail.com,.2hsaltinsoy@erbakan.edu.tr \\ University of Necmettin Erbakan \\ (Konya, Turkey) \\ ${ }^{1}$ Исмаил Таш, ${ }^{2}$ Хавва Сумейра Алтынсой \\ 1'hacili1965@hotmail.com,2hsaltinsoy@erbakan.edu.tr \\ Университет имени Неджметтина Эрбакана \\ (Конья,Турция)
}

\begin{abstract}
Mystical thought is a critical thought developed against official thought and official scientific understanding. This can be observed and discussed separately in both individual and collective layers of mystical life with its religious epistemological in one way and historical, social, political and economic aspects in the other. Specific to this study after the death of the Prophet, the religious sciences that emerged during the tadwin period built on the Arabic language-centered sensualism, and in this regard, it was structured with the Arab form.

None of the above-mentioned built sciences satisfy mystical worldviews. Is this attitude of them a "completion process" or a critical intellectual process? We consider the critical intellectual process as a "critical intellectual and vital" step that includes "completion".

The above dilemma continued in Turkish thought even after joining the Islamic civilization. However, we think that a more comprehensive "Turkish mind", including the Islamic civilization along with its previous cultural resources, is maintained in the wise tradition. In this context, we think that the most fundamental and last form that forms the Turkish mind through Gokturk Script, Kashgari's Dīwān and Yesevism is the Turkish language.
\end{abstract}

Key words. Turkish Language, culture, mind, mysticism, Yesevism.

\section{Introduction}

Leaving aside the political and cultural structuring of the Gokturks and the political and cultural structuring of the Karakhanids in the Islamic period, the emergence and continuation of almost all political structures such as Ghaznavids, Harzemshahs, Mamluks, and Seljuks that emerged depending on the caliphate center after the Turks accepted Islam, as described by Nizam al-Mulk in "Siyasatnama (Book of Government)", seem to have become a fact as a political power affiliated to the caliphate center with the sovereignty obtained after reaching a certain military posture with the rise in the military ranks among the army corps consisting of mewalis or with the nomads taking over the settled life. The com- 
mon aspect in such sovereignties is that nomadic powers preserved the order they seized without disturbing it and kept the administration to the extent that asabiyya (a concept of social solidarity with an emphasis on unity) could be preserved, meaning that they lost their own existence by submitting to the laws of settled life over time.

Since the Uyghurs took over the Gokturks heritage, we can accept the developments in Uyghur literature as the cultural continuity of the same period. We can more clearly see the reasons for the cultural preservation and development of the Turkish existence in the Gokturks and Karakhanids period in terms of form and content when we compare them with the other Turkish states listed above. Therefore, the political structures in question were the reasons why no works were produced in the Turkish language, apart from the works written in the Karakhanids period. For, it is the form that demonstrates, protects, and brings into existence the material. The material indicates whoever the form in question belongs to. For this reason, the states that we have mentioned above have been the continuation of the formal and intellectual traditions, that is, the forms that were previously structured by the Arabs or the Pharisees.

Madrasahs, which emerged as one of the founding elements of these political structures, especially since the $11^{\text {th }}$ and $12^{\text {th }}$ centuries, were also formed as a supporting argument of the same ideological worldviews. In other words, while the literary and political structures of the Turks following the Islamization contributed to the Persian tradition, the madrasahs reiterating the religious sciences shaped by the Arab culture and thought patterns contributed to the spread and universalization of the Arab culture and tradition.

\section{Methodology}

The main method in this article is philosophical anthropology method. The use of this method makes it easier to evaluate the Turkish history, the Turkish thought and the Turkish mystical legends, briefly references of Turkish culture. Using and treating of data which were attained from these sources are owing to ethnographical and anthropological approaches. The proposed method will make it possible to question Yesevism more deeply in context of Turkish mind and Turkish Sufism.

\section{Turkish and Turkish Culture Within the Arab and Persian Structuring}

The Islamization of Turks is attributed to the influence of Iranians rather than Arabs [1, p. 167-182]. This is a correct thought. According to Foltz, the most impressive achievement of the Arab Muslims occurred when they conquered and defeated the entire Persian Sassanid Empire in the 640s. The Abbasid revolution perpetuated the Persian culture which existed before only in one aspect under the new Islamic identity. Islam gradually became Persian in character. To a large extent, Islamic law, philosophy, literature, art, and mysticism all developed in the Persian cultural sphere [2, p. 19-20]. Such considerations are quite general and accurate in terms of the influence of the whole of Central Asia on Islamic thought, with the contribution of the Turks as it is not possible to forget the contributions of Genre thinkers in Fiqh, Hadith, Tafsir, Kalam, Mathematics, and Philosophy. Therefore, these contributions are the joint contributions of Iranian and 
Turkish elements. As a matter of fact, Turkish history and culture is closer to Iranians than Arabs. Turks and Iranians shared a common culture and belief geography together for a long time. In this sense, Iranian, Indian, and Chinese cultures are closer to each other than Islamic and Arab cultures. Along with archaeological and written evidence found elsewhere in Central Asia, religious texts and images found in East Turkestan (also called Xinjiang in Chinese) interestingly attest to the amalgamation of religious ideas from Christianity, Judaism, Buddhism, and Zoroastrianism. It should not be forgotten that especially Manichaeism played its part in this amalgamation and that the east of Central Asia in the pre-modern period was a melting pot of religious traditions. This is because it functions as a remote refuge for heterodox beliefs. The region was the most religiously diverse region in the world until the Mongolian period. According to Foltz, the question of how this multi-religious region became the region almost entirely of Muslims has been one of the most interesting questions in the history of the Silk Road [2, p. 29-30].

In this sense, although we have determined that Iranian and Turkish culture or thinkers contributed to the emergence of religious sciences, we are obliged to accept that the sciences in question were structured in line with the Arab mind and culture with Islamic influence. Therefore, contributions in this direction should be considered as contributions to the Arab mind and culture. The knowledge dimension of these structures has substituted itself for universal Islam and in a sense included itself in the category of the holy. The reason behind all these results is the Arabic language, which is the creative source of literal understanding. The factor that makes the Arabic language so prominent and indispensable is the way Islam emerged and positioned itself against other religions and books. Islam claims to be complementary on the one hand and corrective on the other. However, unlike the previous tradition, Islam has added new arguments that would be very effective in shaping religion and thought in the future. Accordingly:

-The Prophet dictated the revelation he received in a way that no prophet from tradition tried simultaneously. The elements that were dictated after them were collected up to the number of verses and suras and determined in a Mushaf.

-After that, the "Book", which came into the agenda as one of the principles of faith, was also determined.

-As a complementary element of such an understanding of the Book, the structuring of religion in the most general sense is completed, with the claim that the word (kalam) of Allah is in Arabic and that religions before the Qur'an and their holy books have been distorted.

In short, what developments have taken place in relation to the ground that is tried to be depicted? In order to understand this study better, it is necessary to explain the problem more clearly. The problem of "the word of God", which is an ancient problem of the culture of revelation, in which Islam also included itself, has undergone a change of whatness. "The word of God" was reduced to the Arabic language and identified with Arabic. This situation caused Arabic to be blessed with revelation and therefore the Quran to be structured together with Arab culture. Scholars like Shafi started to express that even knowing Arabic would not be enough to understand the Qur'an, that it was necessary to grow up with Arabic culture, in short, the necessity of "being an Arab". It is not surprising to draw such a conclusion from the basic claims of his work 
on the method called "Risale". Religious sciences have structured themselves on such an understanding. Finally, with Rhetoric, which reached its peak in the $13^{\text {th }}$ century, Arabic further consolidated its steady position in Islamic thought and culture. The universalization of Arab thought is thus completed.

Moreover, it deserves serious discussion whether the developing science of Rhetoric has contributed anything other than the sanctification of Arabic. For instance, some verses in the Qur'an that are used as evidence that nothing like it can be produced are actually verses that even ordinary people can understand without any difficulty; however, we should say that the Qur'an has been turned into verses that cannot be understood due to ideological orientations in the direction of its literal interpretation. ${ }^{*}$ Such initiatives only strengthened the place of Arabic and Arab culture among Muslims. This process has not remained just a language problem. At the same time, the approach in question seems to have squeezed the "word of God" problem, which is discussed on a more universal basis such as "logos" and "nous", beyond being a language problem in the entire tradition of religious and philosophical thought, within the boundaries and possibilities of the Arabic language and the Arab mind.

\section{The Place and Importance of Mystic Thought in Islamic Thought}

Sufism, which developed in the $4^{\text {th }}$ century Hijri, emerged as one of the important veins of Islamic thought. As in other sciences, it also based himself on the Qur'an and the Prophet. On the other hand, although the discipline of Sufism accepts the Prophet as an indispensable role model in terms of vital example, it has spoken of a more universal language, the "language of the heart", on the subject of "the word of God", and has emerged with the claim of philosophy of life and knowledge based on the mystical aspect of human nature, whose spectrum anthropologically extends from the mythological aspect to the intellectual aspect. In this sense, Sufis substantially benefited not only from Islam but also from the cultural accumulation of other religions in terms of source. This characteristic of Sufism has enabled the Arab mind to overcome its ideological conservatism in terms of both interpretation and transfer of Islamic thought to life, and has carried Islam to the more universal language of the heart, in which all languages are equal. This situation enabled different cultures to adopt Islam according to their own mental, emotional, and cultural codes and to process it in literary, philosophical, artistic, and aesthetic fields. The importance of Sufism in terms of Turkish thought and culture will be better understood when we consider that the Turks are also located in the mystic culture environment such as the Gokturks, Uyghurs and later

\footnotetext{
* These verses are as follows: And if you are in doubt about what We have sent down upon Our Servant [Muhammad], then produce a surah the like thereof and call upon your witnesses other than Allah, if you should be truthful. But if you do not - and you will never be able to - then fear the Fire, whose fuel is men and stones, prepared for the disbelievers. Baqarah 23-24; Or do they say, "He has made it up"? Rather, they do not believe. Then let them produce a statement like it, if they should be truthful. Tur 33-34; Or do they say, "He invented it"? Say, "Then bring ten surahs like it that have been invented and call upon [for assistance] whomever you can besides Allah, if you should be truthful." Hud 13; Say, "If mankind and the jinn gathered in order to produce the like of this Qur'an, they could not produce the like of it, even if they were to each other assistants." Isra 88.
} 
Zoroastrianism, Buddhism and Manichaeism. In this respect, Sufism contributed to the inclusion of the cultural references of the Turkish mind both in the Islamic culture and in the development and maintenance of its own existence.

In order to accurately reveal the Turkish mind, it is vital to determine how the relevant materials are processed and the perspectives of which sciences should be used in this process. This should be emphasized, especially in regard to Yesevism. We know that the data on Yesevism is mainly related to Sufi literature. Sufi literature, on the other hand, has a wide spectrum ranging from philosophical texts to legends. In other words, Sufi literature includes a literary variety ranging from philosophy to legend, from individual thought to collective thought. Although Ahmed Yesevî, whom we will focus on here, appeared as a sufi scholar and poet personality and identity who grew up with mystical upbringing in the circles of science, Yesevism stands closer to the legendary/heroic side of such a wide literary spectrum. In this sense, Yesevism has very different layered structures in terms of both understanding and explanation. Considering the geography from which it originated and flourished, Yesevism has a special importance for Turks and especially in terms of perceived Turkish religion.

In this context, we only want to analyze two samples from the legends in relation to the change process. The first of these exemplifies how Turkish culture is articulated to a new belief and cultural environment, and the second exemplifies the cultural conflicts experienced in this articulation process.

\section{The Legend of Arslan Bab}

According to a famous story, "Arslan Bab lived for four hundred years, and according to another story, for seven hundred years. The fact that he came to East Turkestan and became an officer in guiding Hodja Ahmed was based on a spiritual sign. In one of the Prophet Muhammad's Holy Wars, the Companions of the Prophet Muhammad somehow starved and came to his presence to ask for some food. Upon the Prophet Muhammad's prayer, Jibril Amin brought a plate of dates from heaven but one of those dates fell to the ground. Jibril said: 'This date is the fate of one of your community named Ahmed Yasawi. Since it is natural for every trust to be given to its owner, The Prophet offered to his companions that one of them should take on this task. None of the Companions responded and only Arslan Bab said that he could take on this task graced with what was ordered by the Prophet. Then, his holiness The Prophet threw that date seed into the mouth of Arslan Baba with his hand and bestowed it from his blessed saliva. Immediately, a curtain became visible on the date and The Prophet ordered Arslan Bab to deal with his education by describing and instructing him on how to find Ahmed Yasawi. Thereupon, Arslan Bab came to Sayram or Yesi, and after fulfilling his duty, he passed away the following year. This legend continued for centuries among the Yasawis. A Yasawi poet named Şems describes this legend in a poem he wrote about Arslan Bab. One day, the Prophet called Arslan Bab and gave him a date and said: 'A child named Ahmed will be born after me; he is the essence of my ummah, find him and give him this date.' Arslan Bab lived for a long time with the blessings of the Prophet's prayer. He continuously kept searching for the owner of the trust. Finally, four hundred years after that date, he 
came to Turkestan, sent news to all parts of his custom, and finally found him on his way to school in Yesi. Arslan Bab greeted the child, and after the child received the greeting, 'O Father, where is your trust?' he asked. Arslan Bab was surprised by this unexpected question asking: 'O Wise Man, how do you know that?'. The child replied, 'God has told me!'. Then he asked for his name and after realizing that it was Ahmed, he handed over the trust to the owner" [3, p. 28-29].

According to the legends, Arslan Bab is Salman-i Farisi, one of the companions of the Prophet [4]. It is not possible for Arslan Bab to be Salman-i Farisi in terms of history. So, how should we understand that Arslan Bab is Salman? If the narratives are evaluated from this point of view, the point we need to understand from this narrative is as follows: Ahmed Yasawi conveyed his holiness directly from the Prophet. This is the reason why Salman-i Farisi lived up to the time of Ahmed Yasawi. In this sense, the important thing in the legends is not the reality of the events, but emphasizing the holiness and spirituality of Ahmed Yasawi in all respects.

Whether Arslan Bab is Salman or not, it is not difficult to understand that this name is related to connecting Yasawi to Ahl al-Bayt. The figure of "Arslan Bab" expresses different connotations. First of all, it is significant that the name consists of the elements "Arslan (Lion)" and "Bab (Gate)" and it is quite open to interpretation. The words "Arslan" and "Bab" cannot be linked with Yasawi's life out of nowhere. Both names have a concept related to Ali in Islamic history. "Arslan" is used to describe his heroism with the epithet of "Asadullah: "Lion of Allah", "Bab" is used as a sign of his wisdom and means the door of true knowledge. Therefore, those who read Yasawi's Wisdoms need to prove whether they should read the words mentioned in this direction in the Divan as "Bab" or "Baba". Even the names, epithets or titles used by Ahmed Yasawi and his close circle can provide us with an opportunity to speculate on this issue. As a matter of fact, we know that the epithet "Ata" was used quite often instead of the name "Baba" in this period. It is very difficult to understand that this name is not "Arslan Ata" but "Arslan Baba" among these epithets. In addition, we leave the use of the word "Baba" in the Yasawi period as a separate issue to the linguists. However, the reason why we prefer the word "Bab" is quite clear. This is because the word bab contains some mystical possibilities in connection with Ali. As a result, this name should be Arslan Bab. Although this determination is falsifiable, it seems more understandable in terms of Turkish history as well as for the cult of "Arslan Bab" living in Central Asia until new information elements are introduced.

"Arslan Bab" points out the importance of the oral tradition, which is one of the main sources that Yesevism feeds on. Considering that Arslan Bab was accepted as one of his companions, it will be seen that this figure expresses the desire of the mythological language to iterate the work to the original source by making the degree of adherence to time and space categories flexible. According to this, the Prophet is the source of religion, and right next to him, Arslan Bab, who is one of the Turks and one of their ancestors, is there. In this respect, Arslan Bab appears as a character suitable for mythological narratives and references. In this respect, Arslan Bab can be considered as a figure that explains the cults of saints and spreads Yesevism among the masses. In this context, we can say that Arslan Bab played the role played by Salman-i Farisi among the Iranians for Turks. In other words, we 
can say that besides the fact that Arslan Bab is a historical figure, as a mythological figure, he is the Salman who has a place in the hearts of Turkish mystics.

There is no doubt that Arslan Bab is also related to the historical context of Turkish thought, apart from the evaluation in the context of Iranian culture. As a matter of fact, the phenomena in question, cosmogonic and mythical thought elements expressing the beginning are not only related to the Islamization process, but also extend to references that are old enough to depict the common character of the ancient heritage of the Turkish mind, which is filtered from very different cultures such as Shamanism, Zoroastrianism, Buddhism, Tengrism.

In this context, the descriptive expressions in the introduction of "Arslan Bab" and "Dede Korkut", as a narrative related to the birth of Yesevism, seem to have a share of the common Turkish imagination: "During the time of the Messenger of Allah's salutation, a soldier from the Bayat tribe, Korkut Ata, appeared. He was the wisest person of Oghuz. Whatever he said would come true. He used to tell news about the invisible world. He was bestowed inspiration by almighty God. Korkut Ata said: In the end of the world, the state will be in the hand of khanate. No one will dare to take it from them till the doomsday. The thing that he mentioned is the Ottomans and still goes on. And he mentioned about similar issues. Korkut Ata would solve the troubles of the Oghuz people. Nothing would be done without consulting Korkut Ata. Any order of his would be welcomed. They would accept and fullfil it" [5, p. 73; 6, p. 385].

As can be seen, it is emphasized in the text that Korkut Ata was an extraordinary person with inspiration and discovery/revelation, and placed next to the Prophet. Whether we call it a diviner, a shaman, a Bodisatva who performs miracles in Buddhism culture, or a wise man or a saint burning with the love of the Prophet, Korkut Ata and Arslan Bab, all represent the same personality. That person is a representative next to the Prophet, who was the Pir of the Turks, trained and disciplined by the Prophet, and who taught Islam to the Turks. In fact, this situation expresses a new beginning and a transition period in terms of the cosmic and cosmogonic fictions of a new world shaped and expressed by the Turks in the language of myth, the stepping stones laid by a type of relationship established by the imagination with reality, a new era in terms of the opposite and the picture of the collective thought in the imagination. In this sense, it is the name of the common culture, way of life and thought of the Turks, together with all its durable elements such as the Yesevism language, culture, imagination, and way of thinking and so on.

\section{The Legend of the Mixed Dhikr Ring of Men and Women That Caused Yasawi's Complaint}

The legend presented below exemplifies the way of articulation of Turkish mind and Turkish culture to a new culture. The legend, which expresses the complaint of Ahmed Yasawi, explains how different beliefs and cultural elements were met by the Turkish mind and how they were tolerated and adopted in their own way. In this sense, the story is structured with a dilemma that expresses the conflicting moods of two different cultures. On the one hand, it tells the arrangement of society and politics based on the mas- 
culine and feminine-like separation of men and women, in which the Arabic language is structured, that is, the understanding of Islam structured with Arab culture and traditions, on the other hand, it tells the elimination of the distinction between men and women, which is a requirement of the nomadic lifestyle and a reflection of the structure of the Turkish language as well as a lifestyle that rejects this dilemma. The story is as follows:

After Hodja Ahmed Yasawi's circle of fame expanded with his followers increased to such an extent that they could be counted in the thousands, the number of his opponents and rivals also increased naturally. Even these hypocrites finally dared to slander. Supposedly, unclothed women attended Hodja's assembly and mingled with men in dhikr. The scholars of Khorasan and ma wara'un-nahr, who strictly adhered to the rules of Shariah, sent inspectors, and as a result of investigating whether this claim was true or not, it was understood that it was just a slander. However, Hodja Ahmed Yasawi wanted to teach them a lesson. One day, while he was sitting in an assembly with his followers, he brought a sealed inkpot and put it out. Addressing the whole congregation, he said: "Who is there among the saints who have never touched their right arm to the women limbs since the day of puberty?" No one could answer. Then, Celal Ata, one of the Sheikh's disciples, appeared. Hodja Ahmed Yasawi gave the inkpot to him and sent it to the countries of ma wara'un-nahr and Khorasan together with the inspectors through him. There, all the scholars and shari'ah scholars united and opened the inkpot. The cotton inside and the fire had never interacted with each other, neither the cotton burned nor the fire went out. At that time, the scholars who had doubted Hodja and sent an inspector clearly understood the meaning of the lesson he wanted to give them. Even if men and women came together in a community of people and continued to pray and worship together, Almighty God was able to destroy all kinds of hatred and enmity in their hearts. Thereupon, all of them were extremely embarrassed and afraid and tried to make amends with gifts and offerings [3, p. 33-34; 7, p. 46-49].*

Essentially, the story in question is about the competition and struggle of two different cultures over the phenomenon of religion. The following issues are raised in the legend:

-The story can be reconstructed through text criticism, but roughly tells us: In Ahmed Yasawi's assembly, there is no classification of men and women in the form of sitting separately, and "unveiled" women participate in dhikr mixed with men, in opposition to the religious perception of "shariahists".

-This situation is not a correct behavior according to the religious perception of the madrasah (ma wara'un-nahr and Khorasan scholars), which is strongly attached to the provisions of the shari'ah. For this reason, the centers in question assign a group of inspectors to investigate whether such an event occurred in Yasawi's assembly. As a result of the investigations, it is determined by the inspectors that the rumors about Yasawi's assembly are not true.

-According to the legend, Yasawi was uneasy even though there was no negative report from the inspection. For this reason, he sends a response to the said centers in

\footnotetext{
*Yasawi's response to this conservative attitude of the ulema found its reflections in Dîvân-ı Hikmet. See Ahmed Yesevî, Dîvân-1 Hikmet’ten Seçmeler, XXV. Hikmet, haz. Kemal Eraslan, Kültür Bakanlığı Yayınları, Ankara, 2000, 189-191.
} 
its own worldview. He sends an inkpot with an envoy he has chosen among his followers, in which fire does not burn the cotton although cotton and fire are found together. When the scholars open the inkpot, they see that the fire does not burn the cotton, and they are embarrassed by Yasawi's great miracle.

The verdict that the rumor that men and women attend the dhikr assembly in a state of discord is nothing but slander, is not a result accepted by the supporters of Yasawi, but consists of the desire of those who adhere to the "sharia". In fact, adherence to sharia is a religious perception structured by official, literal, and sensual religious scholars according to the religious perception of the people in question, the Arabic language, and Arabic customs and traditions. The perception of religion in question is a religious, political, dominant, and official paradigm of a form of relationship that is accepted as a status for free, noble women of the age, with urbanization as a result of the long process of codification, which started after the death of the Prophet and lasted for several centuries. The living paradigm in question has no equivalent in the eyes of the Turks. There is no distinction between men and women in the lifestyle of Turks. Although it is seen that the Arab lifestyle is recommended by the mouth of the government in the urban life of Turks who have accepted Islam, as noted in "Kutadgu Bilig", we can say that this situation is limited to urban life [8].

\section{The Universal language of Yasawi and wisdoms (divan-i hikmet)}

There are some names that are very common and used as common names or epithets for many people. For example, "Mevlana" is one of these epithets; however, over time, these names were attributed to certain people in such a way that they seemed to be identified with them. The epithet "Mevlana" is one of them and for a long time it was considered as a name peculiar to Celaleddin Rumi. On the other hand, "Mevlana" is a name given by the people to the wise men they love in the books that talk about the wise men [9, p. 31]. Similarly, "wisdom" is a name given to the works of dervishes who wrote poetry in Turkestan, but over time, it has been used for the wisdom of Ahmed Yasawi, and when the word wisdom is mentioned, Yasawi's Divan-ı Hikmet comes to mind [3, p. 21].

Some researchers attribute Yasawi's use of Turkish in his wisdom to the aim of conveying religion to his cognates. ${ }^{*}$ This determination is essentially reasonable. Accordingly, nomads know and use Turkish. It is also understood that the reason why Yasawi used Turkish was the nomads. Then, revealing why the language of the nomads was Turkish becomes a priority problem. It is not difficult to guess that the nomads Yasawi dealt with were Turks. However, these regions are mainly the places where the Persian peoples are settled. The Turkization of the geography took place due to the Oghuzs' orientation to the West and their emigration as a result of the Kyrgyz and then the Uyghurs taking over the political dominance of the Gokturk Khanate. The spread of the Turks on Iranian lands, as in Turkestan and ma wara'un-nahr, is due to the collapse of the Orkhon Turkish Empire and the beginning of the collapse of the Uyghurs, who were driven out of what is now Mongolia by the Kyrgyz in the $19^{\text {th }}$ century. When Turkish elements came and joined the Iranian population, including the Sogdians, Turkish and Iranian culture first

* Comp: Fuad Köprülü, Explanation and Corrections, DIB Publications, Ankara, 1984, 189. 
lived together; however, the Turkish language's dominance over Iranian languages and the gradual Turkification of the local population changed the nature of these regions. In this case, anyone who is a little interested in the history of the Turkish language knows that in the time of Yasawi, Turkish was now on the agenda of the Turkish-Islamic world as a functional language. For this reason, it is necessary to add the power and prevalence of Turkish to the reasons why Ahmed Yasawi preferred Turkish. We think that it is also a common misconception to reduce Ahmed Yasawi and Yesevism to nomadic Turkmen who have not yet urbanized. In our opinion, Yasawi's choice of Turkish is a natural and rational choice sociologically, politically, and especially in terms of the proficiency and prevalence of Turkish. To understand this, it is necessary to know the historical rivalry between Persian and Turkish. This is also related to Persian and Turkish domination areas and forms of influence. Turks and Persians are two nations that know and influence each other both before Islam and with the process of Islamization. While discussing this situation over languages, two points should be noted. First, the languages of both Iranians and Turks have attained certain uniformity and are not a standard language in the current sense; on the contrary, both languages continue to exist with different dialects. Secondly, when it comes to the rivalry between Turkish and Persian, it is interpreted as if the situation is always in favor of Persians and Iranians. However, in Central Asia, Turkish is a serious rival of Persian, and Turkish never allowed Persian dominance in Central Asia. In addition, the spread of Turkish is not limited to the regions where Turks live. The spread of Turkish continued by expanding in Iran itself. For example, if Turks and Persians live together in a village, it is said that only the Turkish language survives in that village after a certain period of time [10, p. 50-54].

It is more appropriate for historical reality to see and evaluate Yasawi's preference for the Turkish language in this way. It is therefore necessary to reconsider the different contexts of these different interpretations. As a matter of fact, it is said that Yasawi was famous as the mentor of both Persians and Turks. In this respect, perhaps it is necessary to talk about the language in Yasawi's wisdoms. Rather than Yasawi, the saints, who probably followed in the footsteps of Yasawi, addressed and penetrated the heartland of Turkmens through these poems. Although the Turkish tribes living in the steppe were sincere Muslims, they also adhered to their old traditions. As stated before, there are rumors that men and women coexist in Yasawi's assemblies, which is a necessity of the nomadic life of the Turks. However, according to Islam, which was accepted through the Arab tradition, this situation is not acceptable."

\footnotetext{
*As a matter of fact, in Yusuf Khass Hajib's Kutadgu Bilig, we come across expressions that deny women and men to sit in a mixed manner and recommend that foreign men not be allowed in the house:

"-Don't let the stranger into the house, remove the woman; Before you get involved, experience the person. -Keep women at home at all times; It's not like a woman's inside out.

- Don't let the stranger into the house, don't take the woman out; The eye that sees these women on the street tempts them.

-If the eye does not see, the heart does not desire; O son, if your eyes see, your heart desires.

-If you keep an eye on something, your heart will not flow to anything; Even if one does not desire, one does not fall into anything.

- Do not include women with men in eating and drinking; if you add it, they'll miss the mark." See: Yusuf Has Hacib, Kutadgu Bilig, 1304-4517.
} 
A second reason why Ahmed Yasawi expressed his wisdoms in Turkish should be sought in the "religion and language problem in mystical worldview" that we have mentioned above. We should say that Yasawi's expression of his feelings and thoughts in his mother tongue and in the form of poetry/wisdoms is more valid and has mystical, religious and anthropological dimensions that also govern Yasawi. First of all, the things that Yasawi expressed in his wisdoms consisted of religious feelings and thoughts. Religion, on the other hand, is more related to emotions and emotional exuberance, both ontologically and epistemologically. Religion is first and foremost a way of establishing a relationship with God and reaching him. It may not attract much attention for those who are born and live in religious life and perform its rituals, but neither the beginning of religion nor the life of worship is actually natural and understandable. From the revelation of the prophets to the extraordinary religious experiences of the saints, it is not unusual for ordinary human experiences. Such events, expectations, orientations are always associated with transcending the natural structure of man and going beyond his own material existence and overflowing himself. All priests, prophets, shamans, etc. have reached extraordinary things by having similar experiences. We know that they have made many material and moral preparations to reach these experiences. The history of religions will show that such religious experience and life is almost universal. However, there is no doubt that everyone who has had this experience has expressed their religious experience in a very different way, but in accordance with the way of feeling and thinking of their own people and in their language. As a result, both the preacher and the believers sought ways to benefit from the magical and magical power of the language, and it seems that they benefited from the emotionally stimulating feature of the language both when it was first sent to them and in order to re-establish and re-experience that holiness. Moreover, according to traditional thought, it stimulates not only the souls of people, but also nature and supernatural beings. In this sense, the expression of epics and language in poetic formats in religious traditions has a cognitive, communicative, emotional, and in short, vital meaning. ${ }^{*}$

In terms of Islam, Arabs lived and continued this with their own material, spiritual, cultural, and physiological means. Turks, on the other hand, could only live with their own cultural codes, the universal human natural law that we tried to express above. What Yasawi did among the Turks was to emotionally adapt them to their own cultural codes. In other words, Yasawi carried Islam into a form that Turks would be emotionally satisfied with and could grasp vitally. From this point on, Turks have truly experienced an Islamic life, an Islamic feeling and thought. As a matter of fact, since Divan-ı Hikmet has been circulating for centuries, especially among Eastern and Northern Turks, Uzbeks, Kyrgyz and Volga Turks like a religious and holy book, it is possible to come across its numerous manuscripts and many later editions [3, p. 120]. Moreover, it was also continued by the aforementioned Yasawi dervishes and the conveyance of wisdoms became a tradition among dervishes [3, p. 124]. What should be emphasized here is that the most important means of transferring a meaning, a thought, an emotion to the language of the heart is the mother tongue, which is kneaded with the material and spiritual existence of the human being. At this point, it

\footnotetext{
* Comp: Gavriil Vasilyevich Ksenefontov, Yakut Şamanizmi, trans. Atilla Bağcı, Kömen Yayınları, Konya, 2011, 123.
} 
should be remembered that mystics do not give much credit to the existence of a higher language, such as Arabic, about the language of religion. In their view, since the upper language in religious experience is a language with a divine character, which is more suitable for the nature of the divine and does not find an absolute correspondence in any world language, everyone having religious experience has expressed it in their mother tongue, which is more suitable for emotional enthusiasm. In this sense, we can say that wisdoms are the adaptation of Islam to the Turkish mind and culture, that is, a way of behavior and a vital "sunnah/tradition" of the Turkish language.

How is this possible? It is not possible to evaluate this only as a material language phenomenon. For this, there is a need for an accumulation of consciousness (intellectual enlightenment) in order to approach the owner and first creator of religion, to hear him, to sympathize with him, or rather to understand him. The accumulation of consciousness is a religious experience that the peoples of Central Asia are not alien to as a common culture. It is the common ground of religions such as Mysticism, Zoroastrianism, Manichaeism, and Buddhism. Moreover, these three religions have features that mingle with each other, whether in mysticism, in elements of beliefs, in conceptual level, or in mythological fictions and forms. The same language of culture and meaning has a wide range of meanings from Turkish inscriptions to legends, and is the common language and common mind of the Turkish people in a wide geography stretching from Turkistan to the Balkans. In this sense, it is not surprising to see that the same cultural codes are used, for example, in the stories about the extraordinary lives of the Islamic period mystics and the stories about the extraordinary lives of the pre-Islamic Bodisatvas."

All these have shown us that the Turkish mind is an accumulation of consciousness, and the most important material and spiritual carrier of this is language, and the nature that ensures its survival is politics. For this reason, no mind that has not evolved into politics has been permanent in history. As a matter of fact, the legacy produced and left by the Turkish states, whose founding mind is Persian, and which started and continued their political life depending on the fictionalized structures, is very limited in the name of Turkish culture. In this sense, it is necessary to emphasize the privileged place of Gokturks, Uyghurs, Karakhanids, and Ottomans in Turkish history.

According to this, Yasawi and Yesevism contributed to the formation of a unity of thought among the Turks through mysticism, and despite all the dominance of Arabic and Persian, they were instrumental in the existence of Turkish in the public strata with political support until it became the state language. Together with the Timurids, it paved the way for it to sound at the highest and literary level with the Chagatai language. Thus it played a unifying role. In addition, with the favorable mood created by Yesevism, Islam was tried to be adopted and spread without causing possible confusion in times of conversion, and the acceptance of Islam was facilitated by harmonizing the old cultural elements with the new process. Moreover, this issue turned out to be a trouble-free situation by being associated with old beliefs and customs [11, p. 1-7].

\footnotetext{
*For example, it is enough to compare the Islamic period Haji Bektash's Vilayetname or the legends of Yesevism with the Buddhism-related "The Story of Good and Evil Prince" or the "Kuanşi Impusar" story about the life of a Bodisatvan. See for the comp. James Russell Hamilton, The Story of Good and Evil Prince, trans. Vedat Köken, Turkish Dil Kurumu Yayınları, Ankara, 1998; Şinasi Tekin, Şinasi Tekin, Uygurca Metinler I Kuanşi İm Pusar (Ses İşiten İlah), Türk Dil Kurumu Yayınları, Ankara, 1993.
} 


\section{Conclusion}

It is concluded that just as Shafi'i, while writing his "Risale", in which he established his legal methodology, says that one cannot understand the Qur'an without knowing Arabic, that is, one cannot be a Muslim, making this claim almost to say that one cannot be a Muslim without being Arab and carrying out all his fictions according to the grammar of the Arab mind, so we can admit not only the Arabic or Persian interpretation of Islam but also the claim by Kasghari's in "Divanu Lügati't-Türk" that Turkish is as a leading language as Arabic, the politics of Yusuf Khass Hajib in "Kutadgu Bilig", the wisdoms in Ahmet Yasawi's "Divan" and the interpretation of Islam in Süleyman Hakim Ata's "Bakırgan Kitabı", Yunus's poems singing the love of God in his "Divan", Ali-Shir Navai's claim in the literary field while expressing that Turkish is a more powerful language than Persian in terms of language logic and expressive power in "Muhakematü'l-lügateyn", the saying "There is a way to God from every language" by Aşık Pasha, who went beyond his age, and the tenet of Mercimek Ahmed and Tatar Granny from Kazan, which is the frontline city of the Turkish World, saying "You can't learn religion in a language other than Tatar", the claim, which was formulated by the Kosovar evlad-1 Fatihan in the Balkans, based on the grammar of the Turkish mind, saying "The one who does not speak Turkish does not fear Allah" in the context of Turkish culture of the proverb.

\section{References}

1. Melikof I. Uyur İdik Uyardılar (trans. Turan Alptekin). - İstanbul: Cem Yayınları, 1993. $-288 \mathrm{p}$.

2. Foltz R. C. İpek Yolu Dinleri: Antik Dönemden 15. Yüzylla Kadar Karayolu Ticareti ve Kültürel Etkileşim. - İstanbul: Medrese Yayınları (trans. Aydın Aslan), 2006. - 224 p.

3. Köprülü M. F. Türk Edebiyatında İlk Mutasavvıflar. - Ankara: TTK Yayınları, 1976. $415 \mathrm{p}$.

4. Sertkaya O. F. Nehcü'l-Ferâdis'te ve Ahmed Yesevî Hikmetlerinde Selmân-1 Farisî/ Arslan Baba Menkıbeleri in Milletlerarası Hoca Ahmed Yesevî Sempozyumu Bildirileri. Ankara, 1991.

5. Ergin M. Dede Korkut Kitabı I. - Ankara: TTK Yayınları, 1989. - 240 p.

6. Nevâî A. Ş. Nesâyimü’l Mahabbe min Şemâyimi'l Fütüvve (ed. Kemal Eraslan). Ankara: TDK Yayınları, 1996. - 493 p.

7. Hazînî. Cevâhiru'l-Ebrâr min Emvâc-1 Bihâr (ed. Cihan Okuyucu). - Kayseri: Erciyes Üniversitesi Gevher Nesibe Tıp Enstitüsü Yayınları, 1995. - 219 p.

8. Taş İ. Kutadgu Bilig'de Kadın// Yusuf Has Hacib'in Doğumunun 1000. Yılında Kutadgu Bilig Türk Dünya Görüşünün Şaheseri Uluslararası Sempozyumu Bildirileri. - İstanbul: Şen Yildız Yayıncilık, 2016. - pp. 439-459.

9. Can Ş. Mevlânâ: Hayatı, Şahsiyeti, Fikirleri. - İstanbul: Ötüken Neşriyat, 1997. - 567 p.

10. Barthold V. V. Orta Asya Türk Tarihi (trans. Hüseyin Dağ). - Ankara: Divan Yayınları, 2011. $-276 \mathrm{p}$.

11. Tezcan M. Ahmet Yesevi'nin Türk Din Antropolojisindeki Yeri // Ankara Üniversitesi Eğitim Bilimleri Fakültesi Dergisi 26, no. 1, 1993. - pp. 1-7. 
Таш И., Алтынсой С.

Түрік сана мен сопылықтың діни-мәдени ерекшеліктері: ясауилық

Аңдатnа. Мистикалық ой - бұл ресми ой мен ресми ғылыми түсінікке қарсы жасалған сыни ой. Бұл мәселені бір жағынан діни эпистемологиялық тұрғыдан, екінші жағынан тарихи, әлеуметтік, саяси және экономикалық аспектілер арқылы мистикалық өмірді жеке де, ұжымдық қабаттарда да бақылауға және талқылауға болады. Пайғамбар қайтыс болғаннан кейін, тадвин кезеңінде пайда болған діни ғылымдар араб тіліне бағытталған сенсуализге негізделді және осы тұрғыда араб формасын қолдану арқылы құрастырылды.

Жоғарыда аталған ғылымдардың ешқайсысы мистикалық дүниетанымды қанағаттандырмайды. Бұл қатынас «аяқтау үдерісі» немесе «зияткерлік дағдарыс үдерісі» болып санала ма? Біз зияткерлік сыни дағдарысты «аяқтауды» қамтитын, «зияткерлік сыни және өмірлік маңызды» қадам ретінде қарастырамыз.

Жоғарыдағы дилемма түркі ойында ислам өркениетіне қосылғаннан кейін де жалғасын тапты. Бірақ, біз кеңірек «түрік ақыл-ойын» барлығын, ислам өркениетінің бұрынғы мәдени ресурстарын қамти отырып, даналық дәстүрде сақталады деген ойдамыз. Бұл тұрғыда біз Гөктүрік жазуы, қашқарилық диванның мен ясауилық арқылы түрік сана-сезімін қалыптастыратын ең негізгі және соңғы форма түрік тілі деген тұжырым жасаймыз.

Түйін сөздер. Түрік тілі, мәдениеті, ақыл -ойы, мистицизм, Ясауилық.

Таш И., Алтынсой С.

Религиозно-культурные особенности турецкого сознания и турецкого суфизма: ясавизм

Аннотация. Мистическая мысль - это критическая мысль, развитая против официальной мысли и официального научного понимания. Это можно наблюдать и обсуждать отдельно, как на индивидуальном, так и на коллективном уровнях мистической жизни, с ее религиозно-эпистемологическими, с одной стороны, и историческими, социальными, политическими и экономическими аспектами - с другой. Конкретно для этого исследования после смерти Пророка религиозные науки, возникшие в период тадвин, основывались на ориентированном на арабский язык сенсуализме, и в этом отношении оно было структурировано с использованием арабской формы.

Ни одна из упомянутых выше построенных наук не удовлетворяет мистическому мировоззрению. Является ли такое их отношение «процессом завершения» или критическим интеллектуальным процессом? Мы рассматриваем критический интеллектуальный процесс как «критический интеллектуальный и жизненно важный» шаг, который включает «завершение».

Вышеупомянутая дилемма продолжалась в турецкой мысли даже после присоединения к исламской цивилизации. Однако мы думаем, что более всеобъемлющий «турецкий ум», включая исламскую цивилизацию вместе с eе предыдущими культурными ресурсами, сохраняется в мудрых традициях. В этом контексте мы думаем, что самой фундаментальной и последней формой, которая формирует турецкое сознание посредством письменности Гоктюрк, кашгарийского дивана и ясавизма, является турецкий язык.

Ключевые слова. Турецкий язык, культура, разум, мистика, ясавизм. 